Reified Life 



\title{
Reified Life
}

\author{
Speculative Capital \\ and the Ahuman Condition
}

\author{
J. Paul Narkunas
}

F O R D H A M N I VERS I T Y PRES

New York 2018 
Copyright (C) 2018 Fordham University Press

All rights reserved. No part of this publication may be reproduced, stored in a retrieval system, or transmitted in any form or by any means-electronic, mechanical, photocopy, recording, or any other-except for brief quotations in printed reviews, without the prior permission of the publisher.

Fordham University Press has no responsibility for the persistence or accuracy of URLs for external or third-party Internet websites referred to in this publication and does not guarantee that any content on such websites is, or will remain, accurate or appropriate.

Fordham University Press also publishes its books in a variety of electronic formats. Some content that appears in print may not be available in electronic books.

Visit us online at www.fordhampress.com.

Library of Congress Cataloging-in-Publication Data

Names: Narkunas, J. Paul, author.

Title: Reified life : speculative capital and the ahuman condition / J. Paul Narkunas.

Description: First edition. I New York, NY : Fordham University Press, 20 I 8. I Includes bibliographical references and index.

Identifiers: LCCN 2018004952 | ISBN 9780823280308 (cloth : alk. paper) | ISBN 97808232803 I 5 (pbk. : alk. paper)

Subjects: LCSH: Life. I Human beings. I Humanism. I Forecasting. I Poststructuralism. I Structuralism.

Classification: LCC BD 435 . N37 2018 । DDC I 28 - dc23

LC record available at https://lccn.loc.gov/20I $800495^{2}$

Printed in the United States of America

$$
20 \quad \text { I9 } 18 \quad 5 \quad 4 \quad 3 \quad 2 \quad \text { I }
$$

First edition 